\title{
Evaluation of colostrum bioactive protein transfer and blood metabolic traits in neonatal lambs in the first 24 hours of life
}

\author{
H. L. Zhu, ${ }^{1,2} \oplus$ X. W. Zhao, ${ }^{2}{ }^{\oplus}$ S. Chen, ${ }^{2}$ W. $\operatorname{Tan}^{3}{ }^{3}$ R. W. Han, ${ }^{1}$ Y. X. Qi, ${ }^{2}$ D. W. Huang, ${ }^{2}$ and Y. X. Yang ${ }^{1,2 *}$ (1) \\ ${ }^{1}$ College of Food Science and Engineering, Qingdao Agricultural University, Qingdao 266109, China \\ ${ }^{2}$ Anhui Province Key Laboratory of Livestock and Poultry Product Safety Engineering, Institute of Animal Science and Veterinary Medicine, \\ Anhui Academy of Agricultural Sciences, Hefei 230031, China \\ ${ }^{3}$ Anhui Institute for Food and Drug Control, Hefei 230051, China
}

\begin{abstract}
Colostrum is a unique resource that contributes to the passive transfer of immunity and plays a central role in the health status of neonatal ruminants. However, digestion and absorption of colostral proteins in the gut remain incompletely understood. Therefore, this study aimed to investigate the effect of bovine colostrum feeding on blood metabolic traits and to quantify colostral bioactive proteins in the gastrointestinal digesta and blood to evaluate intestinal transfer in neonatal lambs in the first $24 \mathrm{~h}$ of life. Fifty-four newborn lambs were used in this study, including 27 lambs fed pooled bovine colostrum and slaughtered at $6(\mathrm{C} 6 \mathrm{~h}), 12(\mathrm{C} 12 \mathrm{~h})$, or 24 h (C24h) after birth; 18 lambs not fed any colostrum or milk and slaughtered at birth (N0h) or $24 \mathrm{~h}(\mathrm{~N} 24 \mathrm{~h})$ after birth; and 9 milk-fed lambs slaughtered at $24 \mathrm{~h}$ (M24h) after birth. Lambs receiving colostrum or milk were bottle-fed within the first $2 \mathrm{~h}$ to obtain intakes of $8 \%$ of body weight at birth. Samples of blood and digesta from the abomasum, jejunum, and ileum were collected after slaughter. Serum concentrations of glucose, insulin, total protein, and aspartate aminotransferase were higher in colostrum-fed lambs than in NOh lambs. Serum concentrations of insulin, total protein, insulin-like growth factor 1 , and $\gamma$-glutamyl transpeptidase were higher in C24h lambs than in N24h or M24h lambs. Apparent efficiencies of IgG absorption in C6h, $\mathrm{C} 12 \mathrm{~h}$, and $\mathrm{C} 24 \mathrm{~h}$ lambs were $14.4,26.8$, and $17.2 \%$, respectively, whereas apparent efficiencies of lactoferrin $(\mathrm{LF}), \alpha$-lactalbumin $(\alpha-\mathrm{LA})$, and $\beta$-lactoglobulin $(\beta-$ LG) absorption were very low in colostrum-fed lambs, with mean values of $0.06,0.002$, and $0.003 \%$, respectively. Concentrations of IgG, LF, $\alpha-\mathrm{LA}$, and $\beta-\mathrm{LG}$ in the digesta of the abomasum, jejunum, and ileum
\end{abstract}

Received February 10, 2020.

Accepted July 17, 2020.

*Corresponding author: yyongxin@yahoo.com rapidly decreased from $\mathrm{C} 6 \mathrm{~h}$ to $\mathrm{C} 24 \mathrm{~h}$ lambs, and the disappearance rates of IgG, LF, $\alpha-\mathrm{LA}$, and $\beta$-LG were higher in lambs from $\mathrm{C} 6 \mathrm{~h}$ to $\mathrm{C} 12 \mathrm{~h}(62.1,75.7,91.3$, and $95.0 \%$ for $\operatorname{IgG}, \mathrm{LF}, \alpha-\mathrm{LA}$, and $\beta-\mathrm{LG}$, respectively) than from $\mathrm{C} 12 \mathrm{~h}$ to $\mathrm{C} 24 \mathrm{~h}(34.6,22.5,7.5$, and $2.2 \%$ for IgG, LF, $\alpha-L A$, and $\beta-L G$, respectively). These results indicated that bovine colostrum feeding improved the metabolic and immunological status of lambs, and that ingested colostral IgG was prone to intact uptake into the blood, whereas almost all ingested LF, $\alpha-L A$, and $\beta$-LG disappeared in the lumen of the gastrointestinal tract in a time-dependent manner. The findings provide novel information for exploring selective absorption of colostral compounds in the small intestine of lambs.

Key words: abomasum, bovine colostrum, lamb, small intestine, bioactive protein

\section{INTRODUCTION}

Colostrum, as the first essential food for neonatal mammals, is of critical importance to ensure their health and survival. In ruminants, the complex structure of the syndesmochorial placenta allows only limited transfer of immunoglobulins, predominantly $\mathrm{IgG}$, from the mother to the fetus (Godden et al., 2019; Weaver et al., 2000). Therefore, neonatal ruminants must ingest colostrum within the first hours after birth to acquire passive immunity through IgG internalization in enterocytes, although the molecular mechanism underlying this phenomenon remains unclear (Jochims et al., 1994; Yang et al., 2019). In addition to IgG, colostrum contains highly abundant bioactive proteins, such as lactoferrin $(\mathbf{L F}), \beta-\mathrm{LG}$, and $\alpha-\mathrm{LA}$, that have been reported to enhance the intestinal antimicrobial and antioxidant capacity and regulate the growth and development of the gastrointestinal tract (GIT; Hernández-Castellano et al., 2014; Corrochano et al., 2019).

After ingestion of colostrum, IgG, $\alpha-\mathrm{LA}, \beta-\mathrm{LG}$, and $\mathrm{LF}$ are separated into the whey phase due to curd formation in the abomasum. Subsequently, they pass through 
the small intestine and undergo substantial processing, including degradation in the gut lumen and internalization, retention, hydrolysis, and intact transfer within the intestinal tissue (Yvon et al., 1993; Miyazaki et al., 2017; Yang et al., 2019). Recently, through a proteomics study using 2-dimensional gel electrophoresis coupled with MALDI-TOF mass spectrometry, we found that colostral IgG and $\beta$-LG were clearly internalized in the small intestinal tissue of colostrum-fed calves, whereas $\alpha-\mathrm{LA}$ and LF were not detected (Yang et al., 2019). A proteomics study in piglets demonstrated that colostrum IgG was absorbed and retained within the small intestinal tissue by liquid chromatography coupled with tandem mass spectrometry, whereas $\alpha-\mathrm{LA}, \beta-\mathrm{LG}$, and LF were detected with very low protein scores (Danielsen et al., 2011). An early study reported very low recovery of colostrum $\operatorname{IgG}$ and $\beta-\mathrm{LG}$ in the urine of colostrum-fed lambs (Yvon et al., 1993), suggesting that almost all compounds were degraded or absorbed in the GIT. The intestinal absorption of colostrum IgG in neonatal ruminants is time-dependent, occurring most rapidly during the first $6 \mathrm{~h}$, decreasing from 6 to $12 \mathrm{~h}$, and ceasing at approximately $24 \mathrm{~h}$ (Weaver et al., 2000; Cabral et al., 2012). It is thus of great interest to investigate what happens to colostrum bioactive proteins in the GIT within the first $24 \mathrm{~h}$ of life.

We hypothesized that ingested colostral bioactive proteins may be selectively absorbed in the GIT of neonatal lambs to ensure their health and survival. Here, the primary objective was to investigate temporal changes in IgG, LF, $\alpha-\mathrm{LA}$, and $\beta-\mathrm{LG}$ of the digesta from different GIT regions (abomasum, jejunum, and ileum) and evaluate their intact transfer in neonatal lambs fed bovine colostrum in the first $24 \mathrm{~h}$ of life. In addition, we examined the effects of bovine colostrum feeding on blood metabolic parameters.

\section{MATERIALS AND METHODS}

\section{Collection of Colostrum and Milk}

First milking colostrum was collected from freshly calved cows at the Chuzhou Nanqiao dairy farm (Anhui, China) and frozen in 4-L colostrum bags. Approximately $50 \mathrm{~L}$ of colostrum was collected, and all samples were slowly thawed at room temperature $\left(20^{\circ} \mathrm{C}\right)$ and mixed thoroughly to obtain the pool of colostrum. In addition, $5 \mathrm{~L}$ of fresh bovine milk was collected from a milk tank $\left(4^{\circ} \mathrm{C}\right)$ at this dairy farm. Pooled colostrum and milk were separated into $360-\mathrm{mL}$ plastic bottles and stored at $-20^{\circ} \mathrm{C}$. The IgG, LF, $\alpha-\mathrm{LA}$, and $\beta-\mathrm{LG}$ concentrations in colostrum were 118.8, 0.44, 0.91, and $3.1 \mathrm{~g} / \mathrm{L}$, respectively, and those in milk were $0.55,0.08$, 1.6 , and $3.6 \mathrm{~g} / \mathrm{L}$, respectively.

\section{Animals and Experimental Design}

The animal experiment was conducted at the Anhui Ruijiang Farming Science and Technology Co., Ltd. (China) according to the protocols approved by the Animal Care Advisory Committee of the Anhui Academy of Agricultural Sciences (no. A11-CS16). A total of 54 male $\mathrm{Hu}$ newborn lambs with average birth BW of $3.25 \mathrm{~kg}(\mathrm{SD}=0.30)$ were used in this study. After birth, lambs were immediately separated from their mothers and randomly assigned into 6 groups based on birth BW. Twenty-seven lambs were fed pooled bovine colostrum and slaughtered at $6 \mathrm{~h}(\mathbf{C} 6 \mathbf{h}, \mathrm{n}=9), 12 \mathrm{~h}$ (C12h, $\mathrm{n}=9)$, and $24 \mathrm{~h}(\mathbf{C 2 4 h}, \mathrm{n}=9)$ after birth, respectively; 18 lambs were not fed any colostrum or milk and were slaughtered at birth $($ Noh, $\mathrm{n}=9)$ and $24 \mathrm{~h}$ (N24h, $\mathrm{n}=9$ ) after birth, respectively. The remaining 9 lambs were fed pooled bovine milk and slaughtered at $24 \mathrm{~h}$ (M24h) after birth. Before feeding, colostrum and milk were incubated in a water bath at a constant temperature of $40^{\circ} \mathrm{C}$. Lambs that received colostrum or milk were bottle-fed starting at 20 min after birth at 30-min intervals for the first $2 \mathrm{~h}$ to achieve intake close to $8 \%$ of birth $\mathrm{BW}$. The amount of ingested colostrum or milk was recorded and is shown in Tables 1 and 2 .

\section{Sample Collection}

In brief, 20-mL blood samples without anticoagulants were immediately collected after slaughter and stored overnight at room temperature. Serum was obtained following centrifugation at $3,000 \times g$ for 20 min at $4^{\circ} \mathrm{C}$. The serum was transferred into $1.5-\mathrm{mL}$ microcentrifuge tubes in equal aliquots and frozen at $-20^{\circ} \mathrm{C}$. After slaughter, the abdominal cavity was opened, and the whole GIT was carefully removed within 10 to $15 \mathrm{~min}$. Samples of the gastrointestinal digesta were collected from the abomasum, middle jejunum $(15 \mathrm{~cm})$, and ileum (15 $\mathrm{cm}$ proximal to the ileocecal junction) and stored at $-20^{\circ} \mathrm{C}$. Afterward, all samples were stored at $-80^{\circ} \mathrm{C}$ in the laboratory until analysis.

\section{Sample Analysis}

Serum concentrations of glucose, total protein, total cholesterol, nonesterified fatty acids (NEFA), alkaline phosphatase (ALP), aspartate aminotransferase (AST), and $\gamma$-glutamyl transpeptidase (GGT) were determined by using a clinical biochemistry analyzer (AU5800, Beckman Coulter Inc., Brea, CA) using kits (cat. nos. 190-361, 191-391, 190-834, 190-837, 190-971, 190-506, 190-601; Biosino Bio-Technology and Science Inc., Beijing, China). Serum concentrations of glutathione peroxidase (GSH-Px), superoxide dismutase 
Table 1. Intake of pooled bovine colostrum and whey proteins for neonatal lambs $(\mathrm{n}=9)$

\begin{tabular}{|c|c|c|c|c|}
\hline \multirow[b]{2}{*}{ Item } & \multicolumn{4}{|c|}{ Group $^{1}$} \\
\hline & NOh & C6h & $\mathrm{C} 12 \mathrm{~h}$ & $\mathrm{C} 24 \mathrm{~h}$ \\
\hline Birth BW, kg & $3.33 \pm 0.18$ & $3.16 \pm 0.08$ & $3.19 \pm 0.13$ & $3.35 \pm 0.12$ \\
\hline Colostrum, mL/lamb & - & $255.0 \pm 15.7$ & $251.3 \pm 16.4$ & $283.8 \pm 12.1$ \\
\hline Colostrum, $\%$ of BW & - & $8.05 \pm 0.42$ & $7.93 \pm 0.52$ & $8.55 \pm 0.48$ \\
\hline $\operatorname{IgG}, g / \operatorname{lamb}$ & - & $30.3 \pm 1.9$ & $29.8 \pm 1.9$ & $33.7 \pm 1.4$ \\
\hline $\mathrm{IgG}, \mathrm{g} / \mathrm{kg}$ of $\mathrm{BW}$ & & $9.57 \pm 0.50$ & $9.42 \pm 0.65$ & $10.1 \pm 0.57$ \\
\hline Lactoferrin, mg/lamb & - & $112.4 \pm 6.9$ & $110.7 \pm 7.2$ & $125.0 \pm 5.3$ \\
\hline Lactoferrin, $\mathrm{mg} / \mathrm{kg}$ of $\mathrm{BW}$ & & $35.5 \pm 1.9$ & $35.0 \pm 2.4$ & $37.7 \pm 2.1$ \\
\hline$\alpha-\mathrm{LA}, \mathrm{mg} / \mathrm{lamb}$ & - & $230.7 \pm 14.2$ & $227.3 \pm 14.8$ & $256.7 \pm 10.9$ \\
\hline$\alpha-\mathrm{LA}, \mathrm{mg} / \mathrm{kg}$ of BW & & $72.9 \pm 3.8$ & $71.8 \pm 5.0$ & $77.4 \pm 4.4$ \\
\hline$\beta-\mathrm{LG}, \mathrm{g} / \mathrm{lamb}$ & - & $0.80 \pm 0.05$ & $0.79 \pm 0.05$ & $0.89 \pm 0.04$ \\
\hline$\beta-\mathrm{LG}, \mathrm{g} / \mathrm{kg}$ of $\mathrm{BW}$ & & $0.25 \pm 0.01$ & $0.25 \pm 0.02$ & $0.27 \pm 0.01$ \\
\hline
\end{tabular}

${ }^{1}$ Group: N0h = lambs were not fed any colostrum or milk and slaughtered at 20 min after birth; C6h = lambs were fed pooled bovine colostrum within the first $2 \mathrm{~h}$ and slaughtered at $6 \mathrm{~h}$ after birth; $\mathrm{C} 12 \mathrm{~h}=$ lambs were fed pooled bovine colostrum within the first $2 \mathrm{~h}$ and slaughtered at $12 \mathrm{~h}$ after birth; $\mathrm{C} 24 \mathrm{~h}=$ lambs were fed pooled bovine colostrum within the first $2 \mathrm{~h}$ and slaughtered at $24 \mathrm{~h}$ after birth.

(SOD), and malondialdehyde (MDA) were determined using kits (cat. nos. A006-1, A001-1, A003-1; Nanjing Jiancheng Bioengineering Institute, Nanjing, China) in a visible spectrophotometer (Unico 7200, Unico, Shanghai, China) according to the manufacturer's instructions and run in duplicate. Serum concentrations of insulin, growth hormone (GH), and IGF-1 were analyzed using ELISA kits (cat. nos. KAP1251, KAP1081, KAP1581; BioSource, Nivelles, Belgium) according to the manufacturer's instructions and run in duplicate. The inter-plate coefficients of variation for GSH-Px, SOD, MDA, insulin, GH, and IGF-1 were $6.8,3.3,5.3$, $7.9,9.3$, and $8.2 \%$, respectively.

Concentrations of IgG, LF, $\alpha-\mathrm{LA}$, and $\beta$-LG in the colostrum, milk, serum, and digesta were measured using bovine ELISA quantitation sets (cat. nos. E10-118, E10-126, E10-128, E10-125; Bethyl Laboratories Inc.,
Montgomery, TX). All assays were performed according to the manufacturer's instructions and run in duplicate. Samples of serum from N0h, N24h, and M24h lambs were not diluted, whereas samples of serum and digesta from colostrum-fed lambs were diluted $1: 10^{3}$ to $1: 10^{7}$ times. The inter-plate coefficients of variation for $\mathrm{IgG}, \mathrm{LF}, \alpha-\mathrm{LA}$, and $\beta$-LG were $6.2,4.9,5.0$, and $3.5 \%$, respectively. The apparent efficiency of absorption (AEA) for IgG, LF, $\alpha-\mathrm{LA}$, and $\beta$-LG was calculated using the following formula (Rocha et al., 2007; Moretti et al., 2010):

$$
\mathrm{AEA}=\frac{\text { Serum } \mathrm{X}_{\mathrm{i}}(\mathrm{g} / \mathrm{L}) \times \mathrm{BW}(\mathrm{kg}) \times 0.08(\mathrm{~L} / \mathrm{kg})}{\mathrm{X}_{\mathrm{i}} \text { intake }(\mathrm{g})} \times 100 \%,
$$

where $\mathrm{X}_{\mathrm{i}}$ represents IgG, LF, $\alpha-\mathrm{LA}$, or $\beta-\mathrm{LG}$.

Table 2. Intake of bovine milk or pooled colostrum and whey proteins in lambs at $24 \mathrm{~h}$ after birth $(\mathrm{n}=9)$

\begin{tabular}{|c|c|c|c|}
\hline \multirow[b]{2}{*}{ Item } & \multicolumn{3}{|c|}{ Group $^{1}$} \\
\hline & $\mathrm{N} 24 \mathrm{~h}$ & M24h & $\mathrm{C} 24 \mathrm{~h}$ \\
\hline Birth BW, kg & $3.22 \pm 0.15$ & $3.25 \pm 0.16$ & $3.35 \pm 0.12$ \\
\hline Colostrum/milk, mL/lamb & - & $255.0 \pm 14.4$ & $283.8 \pm 12.1$ \\
\hline Colostrum/milk, $\%$ of BW & - & $7.90 \pm 0.46$ & $8.55 \pm 0.48$ \\
\hline IgG, g/lamb & - & $0.14 \pm 0.01^{\mathrm{b}}$ & $33.7 \pm 1.4^{\mathrm{a}}$ \\
\hline IgG, $\mathrm{g} / \mathrm{kg}$ of $\mathrm{BW}$ & & $0.05 \pm 0.00^{\mathrm{b}}$ & $10.1 \pm 0.57^{\mathrm{a}}$ \\
\hline Lactoferrin, mg/lamb & - & $20.4 \pm 1.18^{\mathrm{b}}$ & $125.0 \pm 5.3^{\mathrm{a}}$ \\
\hline Lactoferrin, $\mathrm{mg} / \mathrm{kg}$ of $\mathrm{BW}$ & & $5.76 \pm 0.48^{\mathrm{b}}$ & $37.7 \pm 2.1^{\mathrm{a}}$ \\
\hline$\alpha-\mathrm{LA}, \mathrm{mg} / \mathrm{lamb}$ & - & $407.0 \pm 23.6^{\mathrm{a}}$ & $256.7 \pm 10.9^{\mathrm{b}}$ \\
\hline$\alpha-\mathrm{LA}, \mathrm{mg} / \mathrm{kg}$ of BW & & $115.2 \pm 9.5^{\mathrm{a}}$ & $77.4 \pm 4.4^{\mathrm{b}}$ \\
\hline$\beta-L G, g / l a m b$ & - & $0.92 \pm 0.05$ & $0.89 \pm 0.04$ \\
\hline$\beta-\mathrm{LG}, \mathrm{g} / \mathrm{kg}$ of $\mathrm{BW}$ & & $0.26 \pm 0.02$ & $0.27 \pm 0.01$ \\
\hline
\end{tabular}

${ }^{\mathrm{a}, \mathrm{b}}$ Values in the same row with different superscripts are significantly different between M24h and C24h lambs $(P<0.05)$.

${ }^{1}$ Group: N24h = lambs were not fed any colostrum or milk and slaughtered at $24 \mathrm{~h}$ after birth; M24h $=$ lambs were fed bovine milk within the first $2 \mathrm{~h}$ and slaughtered at $24 \mathrm{~h}$ after birth; $\mathrm{C} 24 \mathrm{~h}=$ lambs were fed pooled bovine colostrum within the first $2 \mathrm{~h}$ and slaughtered at $24 \mathrm{~h}$ after birth. 


\section{Statistical Analysis}

The individual lamb was used as the experimental unit. All statistical analyses were performed using IBM SPSS software (version 19.0, IBM Corp., Armonk, NY). Before analysis, normal distribution was tested by the Shapiro-Wilk test, and homogeneity of variance was tested using the Levene test. When comparing 2 groups between N0h and N24h lambs and between M24h and C24h lambs, differences were tested by a Student's $t$ test (normal distribution) or a Mann-Whitney U test (non-normal distribution). When comparing more than 2 groups among N0h, C6h, C12h, and C24h lambs, among N24h, M24h, and C24h lambs, and among the abomasal, jejunal, and ileal regions in a given group (C6h, C12h, or C24h lambs), differences were tested by a one-way ANOVA (normal distribution) followed by Tukey's multiple comparison test or a Kruskal-Wallis (no normal distribution) followed by Dunn's multiple comparison test. Data are presented as means \pm standard error. Differences were considered significant at $P$ $<0.05$, and as trends if $0.05<P<0.10$.

\section{RESULTS}

\section{Intake of Colostrum or Milk and Their Components}

Intake of colostrum and its components, including IgG, LF, $\alpha$-LA, and $\beta$-LG, did not differ $(P=0.26)$ among $\mathrm{C} 6 \mathrm{~h}, \mathrm{C} 12 \mathrm{~h}$, and $\mathrm{C} 24 \mathrm{~h}$ lambs (Table 1). Compared with M24h lambs, C24h lambs showed higher intake of IgG, LF, and $\beta$-LG $(P<0.01$, Table 2$)$.

\section{Serum Metabolic Parameters}

As expected, concentrations of serum glucose, insulin, total protein, ALP, AST, GGT, and IGF-1 in N0h lambs were low (Table 3) but they increased rapidly after colostrum feeding $(P<0.01)$. Concentrations of serum GGT and ALP were the highest in C6h lambs among colostrum-fed lambs, but decreased by 55.1 and $48.8 \%$, respectively, in C24h lambs compared with C6h lambs $(P<0.01)$. Concentrations of serum insulin, total proteins, AST, and IGF-1 were increased by 16.2 , 26.0, 200.4, and $119.2 \%$ in C6h lambs, respectively, with peak values observed for total protein and IGF-1 in C12h lambs and for insulin and AST in C24h lambs $(P<0.001)$. The $\mathrm{C} 24 \mathrm{~h}$ lambs had higher serum total cholesterol than $\mathrm{N} 0 \mathrm{~h}, \mathrm{C} 6 \mathrm{~h}$, and $\mathrm{C} 12 \mathrm{~h}$ lambs $(P<$ 0.001). No differences in concentrations of GH, NEFA, MDA, GSH-Px, and SOD among N0h, C6h, C12h, and C24h lambs were observed $(P>0.10)$.

Compared with M24h lambs, C24h lambs had higher serum concentrations of insulin, total protein, total cholesterol, AST, GGT, and IGF-1, and lower serum glucose and GSH-Px concentrations $(P<0.05)$. Serum SOD concentration tended to be lower in $\mathrm{C} 24 \mathrm{~h}$ than in M24h lambs $(P=0.09)$. No differences in serum concentrations of NEFA, ALP, GH, and MDA were observed between M24h and C24h lambs $(P>0.10)$. Compared with N0h lambs, N24h lambs had higher serum concentrations of total cholesterol, GGT, AST, and IGF-1 and lower serum MDA concentration (Table $4, P<0.05)$.

Table 3. Serum metabolic variables of lambs fed pooled bovine colostrum in the first $24 \mathrm{~h}$ of life

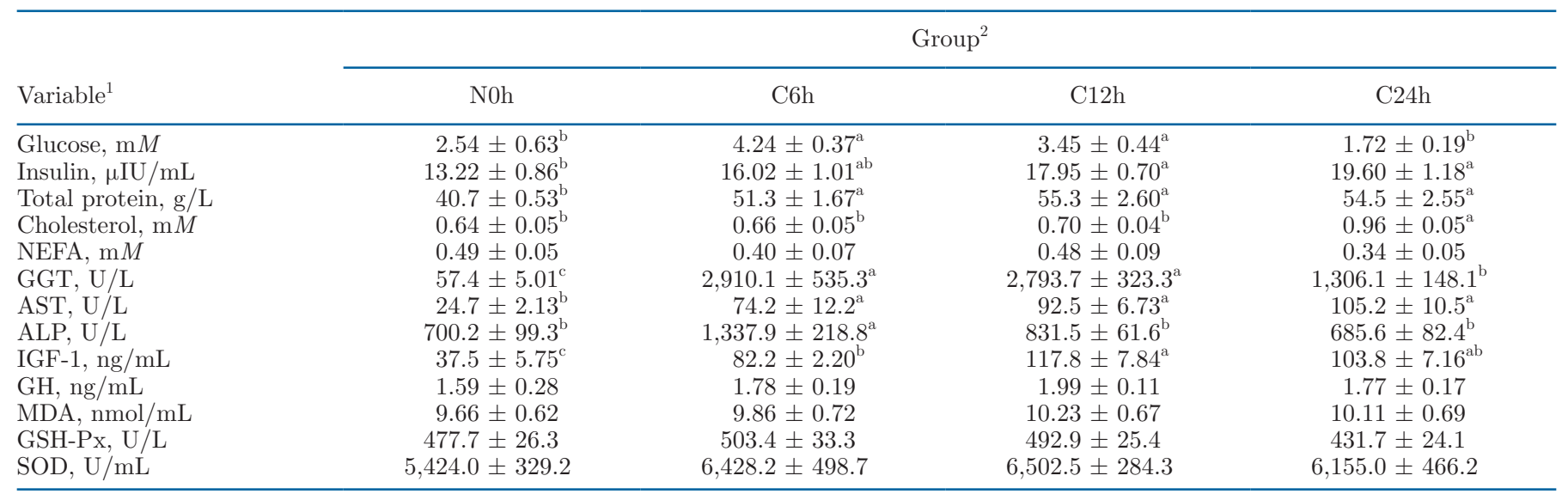

\footnotetext{
${ }^{\mathrm{a}-\mathrm{c}}$ Means within a row with different superscripts differ among groups $(P<0.05)$.

${ }^{1} \mathrm{NEFA}=$ nonesterified fatty acids; GGT $=$ gamma glutamyl transferase; AST $=$ aspartate aminotransferase; ALP $=$ alkaline phosphatase; GH = growth hormone; $\mathrm{MDA}=$ malondialdehyde; $\mathrm{GSH}-\mathrm{Px}=$ glutathione peroxidase; $\mathrm{SOD}=$ superoxide dismutase.

${ }^{2} \mathrm{~N} 0 \mathrm{~h}=$ lambs were not fed any colostrum or milk and slaughtered $20 \mathrm{~min}$ after birth; C6h = lambs were fed pooled bovine colostrum within the first $2 \mathrm{~h}$ and slaughtered at $6 \mathrm{~h}$ after birth; $\mathrm{C} 12 \mathrm{~h}=$ lambs were fed pooled bovine colostrum within the first $2 \mathrm{~h}$ and slaughtered at $12 \mathrm{~h}$ after birth; $\mathrm{C} 24 \mathrm{~h}=$ lambs were fed pooled bovine colostrum within the first $2 \mathrm{~h}$ and slaughtered at $24 \mathrm{~h}$ after birth.
} 


\section{Bioactive Proteins in Serum and Gastrointestinal Digesta}

Concentrations of serum IgG, LF, $\alpha-\mathrm{LA}$, and $\beta-\mathrm{LG}$ in N0h lambs were very low $(0.22 \pm 0.01 \mu \mathrm{g} / \mathrm{mL}$, $5.27 \pm 1.75 \mathrm{ng} / \mathrm{mL}, 0.80 \pm 0.24 \mathrm{ng} / \mathrm{mL}$, and $9.8 \pm$ $3.3 \mathrm{ng} / \mathrm{mL}$, respectively), which were increased after colostrum feeding; IgG concentration was the highest in $\mathrm{C} 12 \mathrm{~h}$ lambs $(32.1 \pm 4.6 \mathrm{mg} / \mathrm{mL})$. Additionally, serum levels of LF and $\beta$-LG reached peak values in C6h lambs $(239.1 \pm 10.3 \mathrm{ng} / \mathrm{mL}$ and $93.0 \pm 3.5 \mathrm{ng} /$ $\mathrm{mL}$, respectively), whereas serum $\alpha$-LA level peaked in C24h lambs (14.1 $\pm 0.91 \mathrm{ng} / \mathrm{mL})$. Lambs in C24h had lower serum IgG concentrations than lambs in $\mathrm{C} 12 \mathrm{~h}$, whereas no differences in serum concentrations of $\mathrm{LF}$, $\alpha-\mathrm{LA}$, and $\beta$-LG were observed among C6h, C12h, and C24h lambs. Similar to the serum IgG concentration, the AEA of IgG was the highest in C12h lambs (26.8 \pm $3.1 \%$, Figure 1A) among colostrum-fed lambs, and no difference was observed between $\mathrm{C} 6 \mathrm{~h}$ and $\mathrm{C} 24 \mathrm{~h}$ lambs. Although higher AEA of $\mathrm{LF}$ and $\beta-\mathrm{LG}$ were observed in C6h than in C24h lambs, AEA of LF, $\alpha-\mathrm{LA}$, and $\beta-\mathrm{LG}$ were very low, with mean values of $0.06,0.002$, and $0.003 \%$ in colostrum-fed lambs, respectively (Figures 2, 3 , and 4 panels A). Concentrations of IgG, $\alpha-\mathrm{LA}, \mathrm{LF}$, and $\beta-\mathrm{LG}$, respectively, in the GIT digesta are shown in Figures 1, 2, 3, and 4 in panels B and C. As shown in Figures 1 to 4 panels B, concentrations of IgG, LF, $\alpha-\mathrm{LA}$, and $\beta-\mathrm{LG}$ in the digesta of the abomasum, jejunum, and ileum rapidly decreased from $\mathrm{C} 6 \mathrm{~h}$ to $\mathrm{C} 24 \mathrm{~h}$ lambs $(P<0.001)$. Of these, the disappearance rates of $\operatorname{IgG}(80.1$ vs. $15.5 \%)$ and $\alpha$-LA (81.9 vs. $16.5 \%)$ in the abomasum were higher in lambs from $\mathrm{C} 6 \mathrm{~h}$ to $\mathrm{C} 12 \mathrm{~h}$ than from $\mathrm{C} 12 \mathrm{~h}$ to $\mathrm{C} 24 \mathrm{~h}$, whereas the disappearance rates of LF (41.0 vs. $58.2 \%$ ) and $\beta$-LG (31.5 vs. $59.3 \%$ ) were lower in lambs from $\mathrm{C} 6 \mathrm{~h}$ to $\mathrm{C} 12 \mathrm{~h}$ than from $\mathrm{C} 12 \mathrm{~h}$ to $\mathrm{C} 24 \mathrm{~h}$. In the small intestine, the mean disappearance rates of the 4 whey proteins, particularly $\alpha$-LA (91.3 vs. $7.5 \%)$ and $\beta$-LG (95.0 vs. 2.2\%), were higher from $\mathrm{C} 6 \mathrm{~h}$ to $\mathrm{C} 12 \mathrm{~h}$ than from $\mathrm{C} 12 \mathrm{~h}$ to $\mathrm{C} 24 \mathrm{~h}$. In C6h lambs, no differences were detected in the digesta $\operatorname{IgG}, \mathrm{LF}$, $\alpha-\mathrm{LA}$, and $\beta$-LG concentrations among GIT regions (Figures 1 to 4, panels $\mathrm{C}$ ). In $\mathrm{C} 12 \mathrm{~h}$ lambs, concentrations of digesta $\alpha-\mathrm{LA}$ and $\beta-\mathrm{LG}$ in the abomasum were higher than those in the jejunum and ileum $(P<0.05)$, whereas no differences in digesta concentrations of $\mathrm{IgG}$ and LF were observed among GIT regions. In C24h lambs, the digesta $\operatorname{IgG}$ concentration in the jejunum was higher than that in the ileum $(P<0.05)$, whereas no differences in the concentrations of digesta LF, $\alpha-L A$, and $\beta-L G$ were observed between the jejunum and ileum. Compared with M24h lambs, C24h lambs had higher concentrations of IgG, LF, $\alpha-\mathrm{LA}$, and $\beta-\mathrm{LG}$ in the digesta of the jejunum and ileum $(P<0.05$; Table 5).

\section{DISCUSSION}

To our knowledge, this study is the first to investigate the temporal changes in IgG, LF, $\alpha-\mathrm{LA}$, and $\beta-\mathrm{LG}$ concentrations in the digesta of the GIT corresponding to those in blood of lambs fed bovine colostrum

Table 4. Serum metabolic variables in neonatal lambs fed without or with pooled bovine colostrum and milk at $24 \mathrm{~h}$ after birth

\begin{tabular}{|c|c|c|c|c|}
\hline Variable $^{1}$ & \multicolumn{4}{|c|}{ Group $^{2}$} \\
\hline Glucose, $\mathrm{m} M$ & $2.54 \pm 0.63$ & $1.52 \pm 0.54^{\mathrm{b}}$ & $2.84 \pm 0.30^{\mathrm{a}}$ & $1.72 \pm 0.19^{\mathrm{b}}$ \\
\hline Total protein, g/L & $40.7 \pm 0.53$ & $40.1 \pm 0.94^{\mathrm{b}}$ & $37.8 \pm 1.17^{\mathrm{b}}$ & $54.5 \pm 2.55^{\mathrm{a}}$ \\
\hline Cholesterol, $\mathrm{m} M$ & $0.64 \pm 0.05^{\mathrm{y}}$ & $0.93 \pm 0.02^{\mathrm{x}, \mathrm{a}}$ & $0.78 \pm 0.03^{\mathrm{b}}$ & $0.96 \pm 0.05^{\mathrm{a}}$ \\
\hline NEFA, $m M$ & $0.49 \pm 0.05$ & $0.40 \pm 0.12$ & $0.44 \pm 0.11$ & $0.34 \pm 0.05$ \\
\hline $\mathrm{AST}, \mathrm{U} / \mathrm{L}$ & $24.7 \pm 2.13^{\mathrm{y}}$ & $95.3 \pm 20.4^{\mathrm{x}, \mathrm{a}}$ & $52.7 \pm 3.24^{\mathrm{b}}$ & $105.2 \pm 10.5^{\mathrm{a}}$ \\
\hline IGF-1, ng/mL & $37.5 \pm 5.75^{\mathrm{y}}$ & $83.5 \pm 7.50^{\mathrm{x}, \mathrm{b}}$ & $79.3 \pm 3.62^{\mathrm{b}}$ & $103.8 \pm 7.16^{\mathrm{a}}$ \\
\hline $\mathrm{GH}, \mathrm{ng} / \mathrm{mL}$ & $1.59 \pm 0.28$ & $1.83 \pm 0.23$ & $1.69 \pm 0.18$ & $1.77 \pm 0.17$ \\
\hline $\mathrm{MDA}, \mathrm{nmol} / \mathrm{mL}$ & $9.66 \pm 0.62^{\mathrm{x}}$ & $7.89 \pm 0.29^{\mathrm{y}, \mathrm{b}}$ & $11.49 \pm 0.41^{\mathrm{a}}$ & $10.11 \pm 0.69^{\mathrm{a}}$ \\
\hline GSH-Px, U/L & $477.7 \pm 26.3$ & $423.6 \pm 18.7^{\mathrm{b}}$ & $518.0 \pm 12.13^{\mathrm{a}}$ & $431.7 \pm 24.1^{\mathrm{b}}$ \\
\hline $\mathrm{SOD}, \mathrm{U} / \mathrm{mL}$ & $5,424.0 \pm 329.2$ & $5,975.2 \pm 288.8$ & $7,163.9 \pm 284.7$ & $6,155.0 \pm 466.2$ \\
\hline
\end{tabular}

\footnotetext{
${ }^{\mathrm{x}, \mathrm{y}}$ Means within a row with different superscripts differ between N0h and N24h lambs $(P<0.05)$.

${ }^{\mathrm{a}-\mathrm{c}}$ Means within a row with different superscripts differ among N24h, M24h, and C24h lambs $(P<0.05)$.

${ }^{1} \mathrm{NEFA}=$ nonesterified fatty acids; GGT $=$ gamma glutamyl transferase; AST $=$ aspartate aminotransferase; ALP $=$ alkaline phosphatase; GH $=$ growth hormone; MDA = malondialdehyde; GSH-Px = glutathione peroxidase; SOD = superoxide dismutase.

${ }^{2} \mathrm{~N} 0 \mathrm{~h}=$ lambs were not fed any colostrum or milk and were slaughtered at 20 min after birth; N24h = lambs were not fed any colostrum or milk and were slaughtered at $24 \mathrm{~h}$ after birth; $\mathrm{M} 24 \mathrm{~h}=$ lambs were fed bovine milk within the first $2 \mathrm{~h}$ and slaughtered at $24 \mathrm{~h}$ after birth; C24h = lambs were fed pooled bovine colostrum within the first $2 \mathrm{~h}$ and slaughtered at $24 \mathrm{~h}$ after birth.
} 

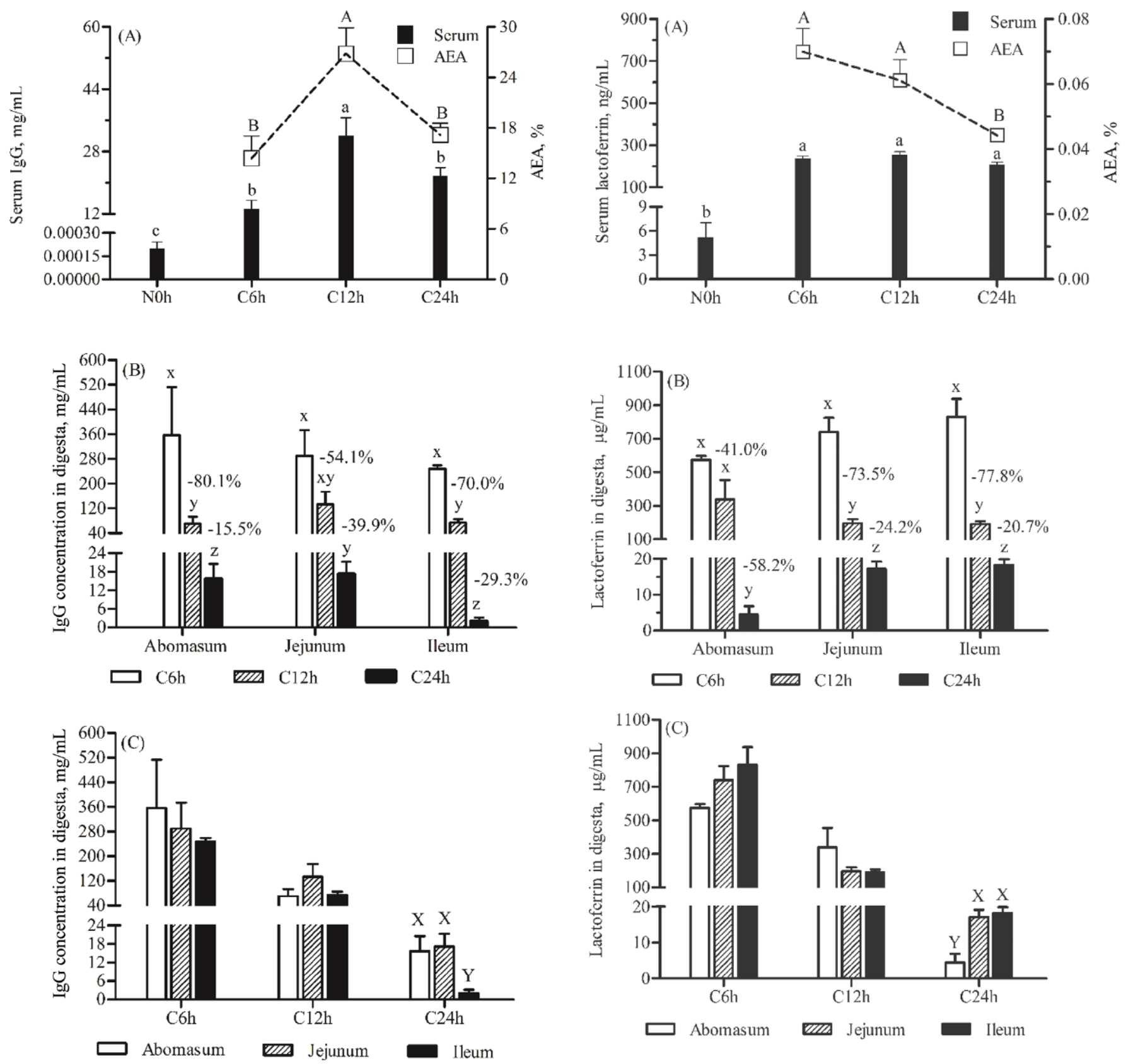

Figure 1. Serum concentration ( $\mathbf{\square})$ and apparent efficiency of absorption (AEA; $\square$ ) of $\operatorname{IgG}(\mathrm{A})$ and $\operatorname{IgG}$ concentration among $\mathrm{C} 6 \mathrm{~h}$, $\mathrm{C} 12 \mathrm{~h}$, and $\mathrm{C} 24 \mathrm{~h}$ lambs (B) at a given gastrointestinal region and among the abomasal, jejunal, and ileal regions at a given group (C). $\mathrm{NOh}=$ lambs were not fed any colostrum or milk and slaughtered 20 min after birth; $\mathrm{C} 6 \mathrm{~h}=$ lambs were fed pooled bovine colostrum within the first $2 \mathrm{~h}$ and slaughtered at $6 \mathrm{~h}$ after birth; $\mathrm{C} 12 \mathrm{~h}=$ lambs were fed pooled bovine colostrum within the first $2 \mathrm{~h}$ and slaughtered at 12 $\mathrm{h}$ after birth; $\mathrm{C} 24 \mathrm{~h}=$ lambs were fed pooled bovine colostrum within the first $2 \mathrm{~h}$ and slaughtered at $24 \mathrm{~h}$ after birth. Letters a-c indicate serum concentration differences among N0h, C6h, C12h, and $\mathrm{C} 24 \mathrm{~h}$ lambs; letters A and B indicate AEA differences among $\mathrm{C} 6 \mathrm{~h}, \mathrm{C} 12 \mathrm{~h}$, and $\mathrm{C} 24 \mathrm{~h}$ lambs; letters $\mathrm{x}-\mathrm{z}$ indicate digesta concentration differences among $\mathrm{C} 6 \mathrm{~h}, \mathrm{C} 12 \mathrm{~h}$, and $\mathrm{C} 24 \mathrm{~h}$ lambs at a given gastrointestinal region; and letters $\mathrm{X}$ and $\mathrm{Y}$ indicate digesta concentration differences among different gastrointestinal regions of lambs at a given group. Results are presented as means $\pm \mathrm{SE}$ and differences are declared at $P<0.05$.

Figure 2. Serum concentration ( $)$ and apparent efficiency of absorption (AEA; $\square$ ) of lactoferrin (A) and lactoferrin concentration among $\mathrm{C} 6 \mathrm{~h}, \mathrm{C} 12 \mathrm{~h}$, and $\mathrm{C} 24 \mathrm{~h}$ lambs at a given gastrointestinal region (B) and among the abomasal, jejunal, and ileal regions at a given group $(\mathrm{C})$. NOh = lambs were not fed any colostrum or milk and slaughtered $20 \mathrm{~min}$ after birth; $\mathrm{C} 6 \mathrm{~h}=$ lambs were fed pooled bovine colostrum within the first $2 \mathrm{~h}$ and slaughtered at $6 \mathrm{~h}$ after birth; $\mathrm{C} 12 \mathrm{~h}$ $=$ lambs were fed pooled bovine colostrum within the first $2 \mathrm{~h}$ and slaughtered at $12 \mathrm{~h}$ after birth; $\mathrm{C} 24 \mathrm{~h}=$ lambs were fed pooled bovine colostrum within the first $2 \mathrm{~h}$ and slaughtered at $24 \mathrm{~h}$ after birth. Letters $\mathrm{a}$ and $\mathrm{b}$ indicate serum concentration differences among NOh, $\mathrm{C} 6 \mathrm{~h}, \mathrm{C} 12 \mathrm{~h}$, and $\mathrm{C} 24 \mathrm{~h}$ lambs; letters A and B indicate AEA differences among $\mathrm{C} 6 \mathrm{~h}, \mathrm{C} 12 \mathrm{~h}$, and $\mathrm{C} 24 \mathrm{~h}$ lambs; letters $\mathrm{x}-\mathrm{z}$ indicate digesta concentration differences among $\mathrm{C} 6 \mathrm{~h}, \mathrm{C} 12 \mathrm{~h}$, and $\mathrm{C} 24 \mathrm{~h}$ lambs at a given gastrointestinal region; and letters $\mathrm{X}$ and $\mathrm{Y}$ indicate digesta concentration differences among different gastrointestinal regions of lambs at a given group. Results are presented as means $\pm \mathrm{SE}$ and differences are declared at $P<0.05$. 

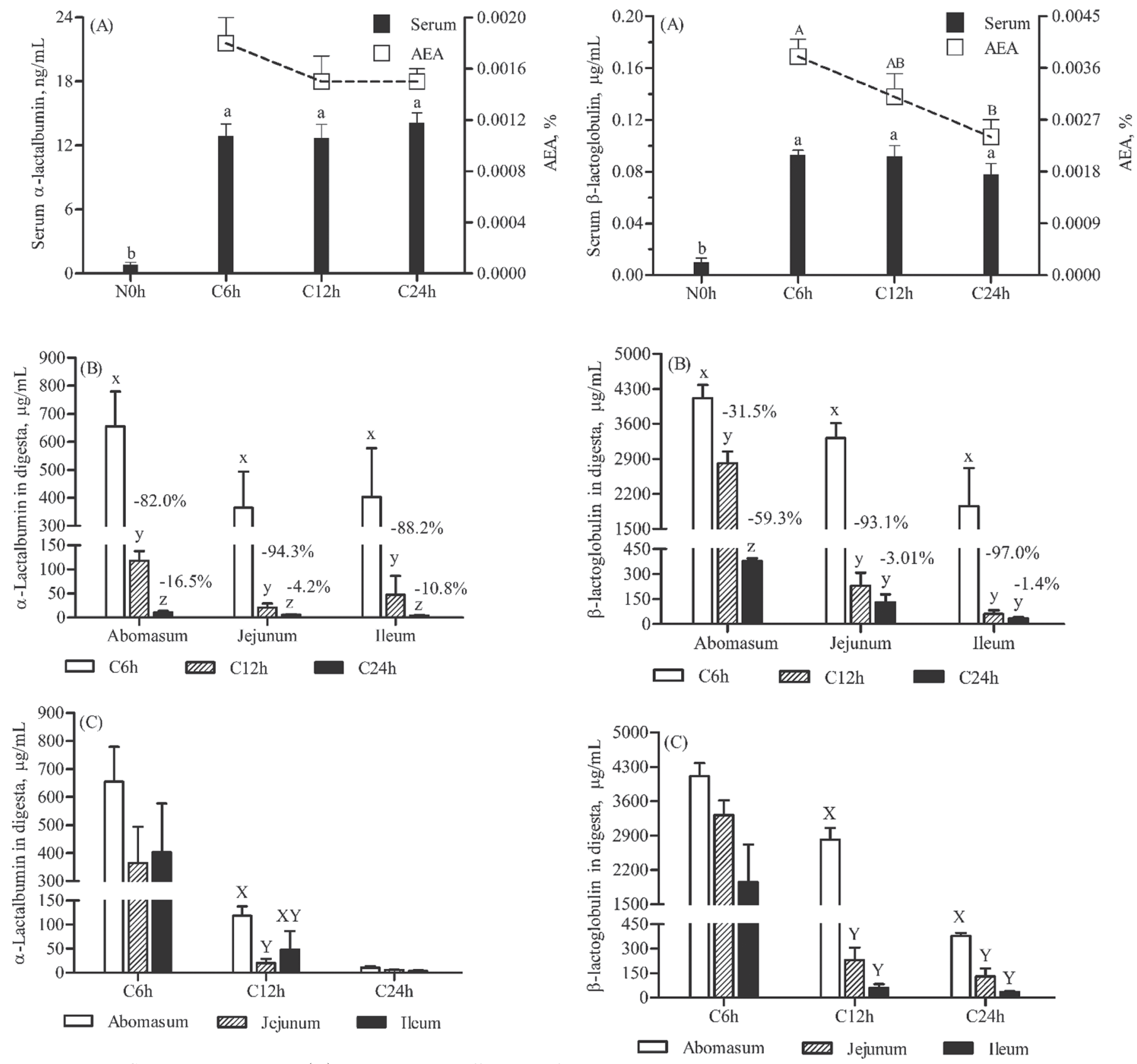

Figure 3. Serum concentration ( $)$ and apparent efficiency of absorption (AEA; $\square$ ) of $\alpha$-LA (A) and $\alpha$-LA concentration among $\mathrm{C} 6 \mathrm{~h}, \mathrm{C} 12 \mathrm{~h}$, and $\mathrm{C} 24 \mathrm{~h}$ lambs at a given gastrointestinal region (B) and among the abomasal, jejunal, and ileal regions at a given group (C). $\mathrm{NOh}=$ lambs were not fed any colostrum or milk and slaughtered 20 min after birth: $\mathrm{C} 6 \mathrm{~h}=$ lambs were fed pooled bovine colostrum within the first $2 \mathrm{~h}$ and slaughtered at $6 \mathrm{~h}$ after birth; $\mathrm{C} 12 \mathrm{~h}=$ lambs were fed pooled bovine colostrum within the first $2 \mathrm{~h}$ and slaughtered at $12 \mathrm{~h}$ after birth; $\mathrm{C} 24 \mathrm{~h}=$ lambs were fed pooled bovine colostrum within the first $2 \mathrm{~h}$ and slaughtered at $24 \mathrm{~h}$ after birth. Letters a and b indicate serum concentration differences among N0h, C6h, C12h, and $\mathrm{C} 24 \mathrm{~h}$ lambs; letters $\mathrm{x}-\mathrm{z}$ indicate digesta concentration differences among $\mathrm{C} 6 \mathrm{~h}, \mathrm{C} 12 \mathrm{~h}$, and $\mathrm{C} 24 \mathrm{~h}$ lambs at a given gastrointestinal region; and letters $\mathrm{X}$ and $\mathrm{Y}$ indicate digesta concentration differences among different gastrointestinal regions of lambs at a given group. Results are presented as means $\pm \mathrm{SE}$ and differences are declared at $P<0.05$.

Figure 4. Serum concentration ( $\mathbf{\square})$ and apparent efficiency of absorption (AEA; $\square$ ) of $\beta$-LG (A) and $\beta$-LG concentration among $\mathrm{C} 6 \mathrm{~h}, \mathrm{C} 12 \mathrm{~h}$, and $\mathrm{C} 24 \mathrm{~h}$ lambs at a given gastrointestinal region (B) and among the abomasal, jejunal, and ileal regions at a given group (C). $\mathrm{NOh}=$ lambs were not fed any colostrum or milk and slaughtered 20 min after birth; $\mathrm{C} 6 \mathrm{~h}=$ lambs were fed pooled bovine colostrum within the first $2 \mathrm{~h}$ and slaughtered at $6 \mathrm{~h}$ after birth; $\mathrm{C} 12 \mathrm{~h}=$ lambs were fed pooled bovine colostrum within the first $2 \mathrm{~h}$ and slaughtered at $12 \mathrm{~h}$ after birth; $\mathrm{C} 24 \mathrm{~h}=$ lambs were fed pooled bovine colostrum within the first $2 \mathrm{~h}$ and slaughtered at $24 \mathrm{~h}$ after birth. Letters a and b indicate serum concentration differences among N0h, C6h, C12h, and $\mathrm{C} 24 \mathrm{~h}$ lambs; letters A and B indicate AEA differences among $\mathrm{C} 6 \mathrm{~h}, \mathrm{C} 12 \mathrm{~h}$, and $\mathrm{C} 24 \mathrm{~h}$ lambs; letters $\mathrm{x}-\mathrm{Z}$ indicate digesta concentration differences among $\mathrm{C} 6 \mathrm{~h}, \mathrm{C} 12 \mathrm{~h}$, and $\mathrm{C} 24 \mathrm{~h}$ lambs at a given gastrointestinal region; and letters $\mathrm{X}$ and $\mathrm{Y}$ indicate digesta concentration differences among different gastrointestinal regions of lambs at a given group. Results are presented as means $\pm \mathrm{SE}$ and differences are declared at $P<0.05$ 
in the first $24 \mathrm{~h}$ of life. As expected, C24h lambs had higher intakes of IgG and LF than M24h lambs due to higher concentrations of IgG and LF in the colostrum. To date, there is no accepted threshold value of serum IgG concentration to determine the success of passive immunity transfer in small ruminants. Successful passive immunity transfer in goat kids is defined as serum IgG concentration $\geq 12 \mathrm{mg} / \mathrm{mL}$ (O'Brien and Sherman, 1993). In lambs, Massimini et al. (2006) reported that the optimal serum IgG concentration ranged from 6 to $16 \mathrm{mg} / \mathrm{mL}$, whereas recent studies have used $15 \mathrm{mg} / \mathrm{mL}$ as the threshold (Alves et al., 2015). To achieve $15 \mathrm{mg} /$ $\mathrm{mL}$ of serum IgG, Alves et al. (2015) noted that lambs required consumption of at least $30 \mathrm{~g}$ of $\mathrm{IgG}$ during the first $24 \mathrm{~h}$ of life. In this study, the IgG intake (mean $\pm \mathrm{SE}$ ) of $\mathrm{C} 6 \mathrm{~h}, \mathrm{C} 12 \mathrm{~h}$, and $\mathrm{C} 24 \mathrm{~h}$ lambs was $30.3 \pm 1.9$, $29.8 \pm 1.9$, and $33.7 \pm 1.4 \mathrm{~g}$, respectively; serum IgG concentration in $\mathrm{C} 24 \mathrm{~h}$ lambs was $21.8 \pm 2.1 \mathrm{mg} / \mathrm{mL}$, and only one animal had less than $15 \mathrm{mg} / \mathrm{mL} \operatorname{IgG}(10.8$ $\mathrm{mg} / \mathrm{mL}$ ). Based on these criteria and the amount of ingested IgG, colostrum feeding management was successful in establishing passive immunity transfer.

The AEA of IgG in neonatal ruminants can be affected by several factors, with the most important being the age of first colostrum feeding and the amount of ingested IgG. In this study, the mean AEA in C24h lambs was $17.2 \%$, which was higher than that reported by Moretti et al. (2010, 2012a) in neonatal lambs and goat kids fed bovine colostrum. Moretti et al. (2010) reported $15.6 \%$ AEA in lambs that received 2 meals of $250 \mathrm{~mL}$ of bovine colostrum containing $115.7 \mathrm{mg} / \mathrm{mL}$ of $\operatorname{IgG}$ at 0 and $6 \mathrm{~h}$. The lower AEA reported by Moretti et al. (2010) in lambs was probably due to excess intake of IgG $(66.1 \mathrm{~g})$, which might reach the physiological limit of transport by enterocytes and interfere with absorptive efficiency. Moretti et al. (2012a) observed that goat kids receiving 3 meals of $190 \mathrm{~mL}$ of lyophilized bovine colostrum containing $55.0 \mathrm{mg} / \mathrm{mL} \mathrm{IgG} \mathrm{at}$ 0,7 , and $14 \mathrm{~h}$ had only 9.5\% AEA. The lower AEA reported by Moretti et al. (2012a) in goat kids was probably attributed to the low IgG intake within the first $6 \mathrm{~h}(10.5 \mathrm{~g})$, although the total IgG intake (31.4 g) within the first $24 \mathrm{~h}$ was similar to that provided in this study (33.7 g). A recent study in calves confirmed that the AEA was influenced more by the mass of IgG consumed within the first several hours than by age at the first colostrum feeding (Osaka et al., 2014). As discussed previously, feeding lambs with colostrum at approximately $8.6 \%$ of $\mathrm{BW}$ within the first $2 \mathrm{~h}$ after birth (Table 1) in this study might have reduced the rate of abomasal emptying, followed by reduced intestinal absorption of IgG (Sakai et al., 2012; Conneely et al., 2014). Moreover, the effects of colostrum sources on IgG absorption were investigated, and no differences in serum IgG and its AEA, or in gamma globulin and albumin, were observed in goat kids receiving an equal amount of $\mathrm{IgG}$ from either goat or bovine colostrum (Moretti et al., 2012a; Lima et al., 2013), although differences in the composition of colostrum between goat and bovine have been reported in previous studies (Csapó et al., 1994; Moretti et al., 2012a; HernándezCastellano et al., 2016). It appears that IgG absorption might not be influenced by feeding goat kids with bovine or goat colostrum. To date, no similar study has been performed in neonatal lambs fed bovine and sheep colostrum. Variations in the composition of colostrum between sheep and cows have been reported (Csapó et al., 1994; Moretti et al., 2010; Hernández-Castellano et al., 2016); therefore, further studies are required to evaluate the effects of feeding neonatal lambs with bovine and sheep colostrum on serum IgG and its AEA using the same experimental conditions, including the age at first feeding, volume, IgG concentration, and feeding interval.

In addition to establishing passive immunity transfer, colostrum intake can affect metabolic traits by stimulating the development and maturation of the GIT and enhancing intestinal absorption of compounds in

Table 5. Concentrations of $\operatorname{IgG}, \alpha-\mathrm{LA}, \beta-\mathrm{LG}$, and lactoferrin in the gastrointestinal digesta of neonatal lambs fed bovine milk or pooled colostrum at $24 \mathrm{~h}$ after birth $(\mathrm{n}=9)^{1}$

\begin{tabular}{|c|c|c|c|c|c|c|}
\hline Item & \multicolumn{2}{|c|}{ Abomasum } & \multicolumn{2}{|c|}{ Jejunum } & \multicolumn{2}{|c|}{ Ileum } \\
\hline $\begin{array}{l}\mathrm{IgG}, \mu \mathrm{g} / \mathrm{mL} \\
\alpha-\mathrm{LA}, \mu \mathrm{g} / \mathrm{mL} \\
\beta-\mathrm{LG}, \mu \mathrm{g} / \mathrm{mL} \\
\text { Lactoferrin, } \\
\mu \mathrm{g} / \mathrm{mL}\end{array}$ & $\begin{aligned} 1,317.1 & \pm 524.4^{\mathrm{b}} \\
0.64 & \pm 0.21^{\mathrm{b}} \\
6.90 & \pm 1.96^{\mathrm{b}} \\
2.75 & \pm 1.58\end{aligned}$ & $\begin{aligned} 15,649.9 & \pm 4,943.7^{\mathrm{a}} \\
10.5 & \pm 3.3^{\mathrm{a}} \\
377.5 & \pm 18.2^{\mathrm{a}} \\
4.48 & \pm 2.31\end{aligned}$ & $\begin{array}{l}13.0 \pm 1.9^{\mathrm{b}} \\
0.04 \pm 0.01^{\mathrm{b}} \\
0.31 \pm 0.03^{\mathrm{b}} \\
0.24 \pm 0.05^{\mathrm{b}}\end{array}$ & $\begin{aligned} 17,214.0 & \pm 4,114.4^{\mathrm{a}} \\
5.43 & \pm 1.17^{\mathrm{a}} \\
130.0 & \pm 49.2^{\mathrm{a}} \\
17.2 & \pm 2.0^{\mathrm{a}}\end{aligned}$ & $\begin{array}{l}0.85 \pm 0.26^{\mathrm{b}} \\
0.05 \pm 0.02^{\mathrm{b}} \\
0.43 \pm 0.05^{\mathrm{b}} \\
0.11 \pm 0.02^{\mathrm{b}}\end{array}$ & $\begin{aligned} 1,907.8 & \pm 1,256.6^{\mathrm{a}} \\
4.03 & \pm 1.09^{\mathrm{a}} \\
34.0 & \pm 5.8^{\mathrm{a}} \\
18.3 & \pm 1.5^{\mathrm{a}}\end{aligned}$ \\
\hline
\end{tabular}

\footnotetext{
${ }^{\mathrm{a}, \mathrm{b}}$ Values in the same row with different superscripts are significantly different between M24h and C24h lambs at a given gastrointestinal region $(P<0.05)$.

${ }^{1} \mathrm{M} 24 \mathrm{~h}=$ lambs were fed bovine milk within the first $2 \mathrm{~h}$ and slaughtered at $24 \mathrm{~h}$ after birth; C24h = lambs were fed pooled bovine colostrum within the first $2 \mathrm{~h}$ and slaughtered at $24 \mathrm{~h}$ after birth.
} 
neonatal ruminants (Hammon and Blum, 1998; Tsiligianni et al., 2012; Hernández-Castellano et al., 2015). We observed that serum concentrations of insulin, total protein, cholesterol, GGT, ALP, AST, and IGF-1 were increased after calves were fed colostrum, as shown in previous studies on colostrum-fed calves and lambs (Hammon and Blum, 1998; Britti et al., 2005; Inabu et al., 2019). In particular, serum concentrations of GGT and ALP reached peak levels in C6h lambs and then decreased in C24h lambs. Our results agreed with those of Kurz and Willett (1991), who reported that the highest serum concentrations of GGT and ALP occurred at $6 \mathrm{~h}$ when calves received 2 feedings of $4 \%$ of birth BW of colostrum at 1 and $13 \mathrm{~h}$ after birth. In addition, serum GGT concentrations in M24h and N24h lambs were lower than that in C24h lambs in our study. This finding indicated that serum GGT was primarily derived from intestinal absorption of colostrum GGT in neonatal calves (Gregory, 2003; Britti et al., 2005). Interestingly, several previous studies reported that the second meal of colostrum feeding at 10 to $15 \mathrm{~h}$ after birth did not result in further increases in serum GGT concentration at $24 \mathrm{~h}$ (Baumrucker et al., 1994; Hadorn and Blum, 1997), and even caused a decrease (Kurz and Willett, 1991). Colostral IgG was intestinally absorbed by pinocytosis, and GGT was also readily absorbed at the same time as IgG (Hadorn and Blum, 1997; Wesselink et al., 1999). We speculate that serum GGT could be degraded in the blood due to the lack of a receptor, such as the neonatal Fc receptor for binding to $\operatorname{IgG}$, in the capillary endothelium to protect against its degradation. Unlike GGT, serum ALP is primarily derived from the brush border of small intestines in calves receiving colostrum (Kurz and Willett, 1991; Britti et al., 2005). However, serum ALP was abruptly decreased in lambs from $\mathrm{C} 6 \mathrm{~h}$ to $\mathrm{C} 24 \mathrm{~h}$, and no differences in serum ALP concentration were observed in C24h lambs compared with those in N0h, N24h, or M24h lambs. This result indicated that intestinal absorption of colostrum ALP might be an important reason for the increased serum ALP because colostrum contains relatively high levels of ALP (Zanker et al., 2001).

In this study, we observed that IgG, LF, $\alpha$-LA, and $\beta-L G$ concentrations were relatively constant among the 3 GIT regions in C6h lambs. Several previous studies have reported that colostral proteins in the abomasum are markedly resistant to proteolytic degradation (Yvon et al., 1993; Danielsen et al., 2011) due to the presence of many protease inhibitors in colostrum (Quigley et al., 1995; McGrath et al., 2016). In addition, the disappearance rates of $\operatorname{IgG}$ and $\alpha-\mathrm{LA}$ were at least $80 \%$, whereas those of LF and $\beta$-LG were approximately $40 \%$ in lambs from $\mathrm{C} 6 \mathrm{~h}$ to $\mathrm{C} 12 \mathrm{~h}$ relative to those from $\mathrm{C} 12 \mathrm{~h}$ to $\mathrm{C} 24 \mathrm{~h}$ in the abomasum. This result suggested that abomasal emptying of $\operatorname{IgG}$ and $\alpha$-LA was faster than that of $\mathrm{LF}$ and $\beta$-LG within 6 to $12 \mathrm{~h}$. Coincidentally, absorption of colostral $\mathrm{IgG}$ in the small intestine of neonatal ruminants primarily occurred in the first $12 \mathrm{~h}$ of life (Cabral et al., 2012; Osaka et al., 2014), implying that IgG and $\alpha$-LA were probably of greater importance as early sources of IgG and amino acids in the small intestines to ensure passive immunity protection and intestinal development (Yvon et al., 1993). The small intestine is the most important site for the digestion and absorption of colostrum components in neonatal ruminants, and the concentrations of whey proteins in the small intestinal digesta depend either on their transfer from the intestinal lumen into blood or on intestinal degradation. We found that more than $94 \%$ of the IgG, LF, $\alpha-\mathrm{LA}$, and $\beta-\mathrm{LG}$ in the digesta of the jejunum and ileum from $\mathrm{C} 6 \mathrm{~h}$ to $\mathrm{C} 24 \mathrm{~h}$ lambs disappeared, suggesting that these whey proteins underwent substantial degradation in the small intestinal lumen, particularly in the first 12 $\mathrm{h}$ of life. Based on the results of serum concentrations and AEA, we observed marked differences in the intact transfer of colostral IgG, LF, $\alpha-\mathrm{LA}$, and $\beta-\mathrm{LG}$; IgG was more prone to cross the intestinal barrier, whereas LF, $\alpha-\mathrm{LA}$, and $\beta$-LG barely crossed the barrier. Recently, internalized IgG and $\beta$-LG but not $\alpha$-LA and LF were detected in the small intestine of colostrum-fed calves (Yang et al., 2019). A study with neonatal piglets using a proteomics approach showed a higher IgG score and lower LF, $\alpha$-LA, and $\beta$-LG scores in the small intestine than in the abomasal digesta (Danielsen et al., 2011). In addition, the activities of digestive enzymes in the small intestinal mucosa such as aminopeptidase A, aminopeptidase $\mathrm{N}$, and dipeptidyl peptidase IV were increased in neonatal calves and goat kids that received colostrum (Blättler et al., 2001; Moretti et al., 2012b). As discussed previously, our results suggested that colostral bioactive proteins were selectively internalized and degraded in the small intestine, which in turn provides evidence for further study of the digestion and absorption of colostral compounds and bioactive substrates in neonatal ruminants. Although our study could facilitate the determination of the intestinal absorption of bovine colostral proteins in neonatal lambs, the temporal changes in the concentrations of these proteins in the digesta and blood could not completely clarify their digestion and absorption. To determine how colostral proteins are degraded or absorbed, further investigations are required, using the total digesta from each GIT region and labeled proteins, to evaluate degradation in the intestinal lumen and internalization and transfer across the intestine into the blood.

Moreover, higher concentrations of IgG, LF, $\alpha-\mathrm{LA}$, and $\beta-\mathrm{LG}$ in the digesta of the small intestine were observed in C24h lambs than in M24h lambs, despite the 
fact that higher $\alpha$-LA intakes were observed in M24h lambs (Table 2). This result can probably be attributed to the faster degradation of milk proteins than colostrum proteins in the GIT to meet the requirements of host growth and development in lambs because of the low amount of nutritional and bioactive substances in milk compared with colostrum (Fischer-Tlustos et al., 2020). In addition, as discussed earlier, many protease inhibitors present in colostrum protect colostral proteins against proteolytic degradation in the abomasum (Yvon et al., 1993; Quigley et al., 1995; McGrath et al., 2016). Using a label-free proteomics approach, we also found that the relative abundances of several protease inhibitors, such as serpin A3-7 and early lactation protein, were higher in the jejunal digesta of colostrumfed calves than in that of milk-fed calves (Wang et al., 2020). We speculate that the higher abundance of protease inhibitors in jejunal digesta may contribute to the resistance of colostral bioactive proteins to degradation in the GIT in C24h lambs.

\section{CONCLUSIONS}

Feeding bovine colostrum improved the metabolic and immunological status of neonatal lambs. Colostral IgG was prone to intact absorption in the intestine and transport into the blood. However, LF, $\alpha$-LA, and $\beta$-LG showed trace levels in the blood, and almost all of the ingested colostral LF, $\alpha-\mathrm{LA}$, and $\beta-\mathrm{LG}$ disappeared in the lumen of the GIT in a time-dependent manner. This study is the first to investigate what happens to colostral bioactive proteins in the abomasal, jejunal, and ileal regions of neonatal ruminants in the first 24 $\mathrm{h}$ of life. The findings reveal the temporal changes in colostral bioactive proteins in the digesta of the GIT and blood in neonatal lambs, which in turn provide evidence for further study of the intestinal absorption of colostral compounds and bioactive proteins in neonatal ruminants using labeled proteins and the total digesta from each GIT region.

\section{ACKNOWLEDGMENTS}

This work was supported by the Projects for Key Research and Development of Anhui Province (1804a07020115) and the Talent Introduction Fund of Anhui Academy of Agricultural Sciences (Hefei, China). The authors have not stated any conflicts of interest.

\section{REFERENCES}

Alves, A. C., N. G. Alves, I. J. Ascari, F. B. Junqueira, A. S. Coutinho, R. R. Lima, J. R. Perez, S. O. De Paula, I. F. Furusho-Garcia, and L. R. Abreu. 2015. Colostrum composition of Santa Ines sheep and passive transfer of immunity to lambs. J. Dairy Sci. 98:3706-3716. https://doi.org/10.3168/jds.2014-7992.

Baumrucker, C. R., M. H. Green, and J. W. Blum. 1994. Effects of dietary rhIGF-I in neonatal calves on the appearance of glucose, insulin, D-xylose, globulins and gamma-glutamyl transferase in blood. Domest. Anim. Endocrinol. 11:393-403. https://doi.org/10 .1016/0739-7240(94)90011-6.

Blättler, U., H. M. Hammon, C. Morel, C. Philipona, A. B. Rauprich, V. Romé, I. Le Huërou-Luron, P. Guilloteau, and J. W. Blum. 2001. Feeding colostrum, its composition and feeding duration variably modify proliferation and morphology of the intestine and digestive enzyme activities of neonatal calves. J. Nutr. 131:12561263. https://doi.org/10.1093/jn/131.4.1256.

Britti, D., G. Massimini, A. Peli, A. Luciani, and A. Boari. 2005. Evaluation of serum enzyme activities as predictors of passive transfer status in lambs. J. Am. Vet. Med. Assoc. 226:951-955. https://doi .org/10.2460/javma.2005.226.951.

Cabral, R. G., E. J. Kent, D. M. Haines, and P. S. Erickson. 2012. Addition of sodium bicarbonate to either 1 or 2 feedings of colostrum replacer: Effect on uptake and rate of absorption of immunoglobulin G in neonatal calves. J. Dairy Sci. 95:3337-3341. https://doi .org/10.3168/jds.2011-5137.

Conneely, M., D. P. Berry, J. P. Murphy, I. Lorenz, M. L. Doherty, and E. Kennedy. 2014. Effect of feeding colostrum at different volumes and subsequent number of transition milk feeds on the serum immunoglobulin G concentration and health status of dairy calves. J. Dairy Sci. 97:6991-7000. https://doi.org/10.3168/jds.2013-7494.

Corrochano, A. R., Y. Sariçay, E. Arranz, P. M. Kelly, V. Buckin, and L. Giblin. 2019. Comparison of antioxidant activities of bovine whey proteins before and after simulated gastrointestinal digestion. J. Dairy Sci. 102:54-67. https://doi.org/10.3168/jds.2018 $-14581$.

Csapó, J., Z. Csapó-Kiss, T. G. Martin, J. Szentpeteri, and G. Wolf. 1994. Composition of colostrum from goats, ewes and cows producing twins. Int. Dairy J. 4:445-458. https://doi.org/10.1016/ 0958-6946(94)90058-2.

Danielsen, M., L. J. Pedersen, and E. Bendixen. 2011. An in vivo characterization of colostrum protein uptake in porcine gut during early lactation. J. Proteomics 74:101-109. https://doi.org/10 .1016 /j.jprot.2010.08.011.

Fischer-Tlustos, A. J., K. Hertogs, J. K. van Niekerk, M. Nagorske, D. M. Haines, and M. A. Steele. 2020. Oligosaccharide concentrations in colostrum, transition milk, and mature milk of primi- and multiparous Holstein cows during the first week of lactation. J. Dairy Sci. 103:3683-3695. https://doi.org/10.3168/jds.2019-17357.

Godden, S. M., J. E. Lombard, and A. R. Woolums. 2019. Colostrum management for dairy calves. Vet. Clin. North Am. Food Anim. Pract. 35:535-556. https://doi.org/10.1016/j.cvfa.2019.07.005.

Gregory, N. G. 2003. Effect of enhancing curd formation during the first colostrum feed on absorption of gamma glutamyl transferase by newborn calves. Aust. Vet. J. 81:549-552. https://doi.org/10 .1111/j.1751-0813.2003.tb12885.x.

Hadorn, U., and W. Blum. 1997. Effects of feeding colostrum, glucose or water on the first day of life on plasma immunoglobulin G concentrations and $\gamma$-glutamyltransferase activities in calves. Zentralbl. Veterinarmed. A 44:531-537. https://doi.org/10.1111/ j.1439-0442.1997.tb01139.x.

Hammon, H. M., and J. W. Blum. 1998. Metabolic and endocrine traits of neonatal calves are influenced by feeding colostrum for different durations or only milk replacer. J. Nutr. 128:624-632. https://doi.org/10.1093/jn/128.3.624.

Hernández-Castellano, L. E., A. M. Almeida, N. Castro, and A. Argüello. 2014. The colostrum proteome, ruminant nutrition and immunity: A review. Curr. Protein Pept. Sci. 15:64-74. https://doi .org/10.2174/1389203715666140221124622.

Hernández-Castellano, L. E., A. M. Almeida, J. Renaut, A. Argüello, and N. Castro. 2016. A proteomics study of colostrum and milk from the two major small ruminant dairy breeds from the Canary Islands: A bovine milk comparison perspective. J. Dairy Res. 83:366-374. https://doi.org/10.1017/S0022029916000273. 
Hernández-Castellano, L. E., A. Morales-delaNuez, D. SánchezMacías, I. Moreno-Indias, A. Torres, J. Capote, A. Argüello, and N. Castro. 2015. The effect of colostrum source (goat vs. sheep) and timing of the first colostrum feeding ( $2 \mathrm{~h}$ vs. $14 \mathrm{~h}$ after birth) on body weight and immune status of artificially reared newborn lambs. J. Dairy Sci. 98:204-210. https://doi.org/10.3168/jds.2014 -8350 .

Inabu, Y., J. Pyo, S. Pletts, L. L. Guan, M. A. Steele, and T. Sugino. 2019. Effect of extended colostrum feeding on plasma glucagon-like peptide-1 concentration in newborn calves. J. Dairy Sci. 102:4619 4627. https://doi.org/10.3168/jds.2018-15616.

Jochims, K., F. J. Kaup, W. Drommer, and M. Pickel. 1994. An immunoelectron microscopic investigation of colostral IgG absorption across the intestine of newborn calves. Res. Vet. Sci. 57:75-80. https://doi.org/10.1016/0034-5288(94)90085-X.

Kurz, M. M., and L. B. Willett. 1991. Carbohydrate, enzyme, and hematology dynamics in newborn calves. J. Dairy Sci. 74:2109-2118. https://doi.org/10.3168/jds.S0022-0302(91)78383-5.

Lima, A. L., D. B. Moretti, W. M. Nordi, P. Pauletti, I. Susin, and R. Machado-Neto. 2013. Eletrophoretic profile of serum proteins of goat kids fed with bovine colostrum in natura and lyophilized. Small Rumin. Res. 113:278-282. https://doi.org/10.1016/j .smallrumres.2013.02.013.

Massimini, G., A. Peli, A. Boari, and D. Britti. 2006. Evaluation of assay procedures for prediction of passive transfer status in lambs. Am. J. Vet. Res. 67:593-598. https://doi.org/10.2460/ajvr.67.4 .593.

McGrath, B. A., P. F. Fox, P. L. H. McSweeney, and A. L. Kelly. 2016. Composition and properties of bovine colostrum: A review. Dairy Sci. Technol. 96:133-158. https://doi.org/10.1007/s13594 $-015-0258-x$.

Miyazaki, T., K. Okada, and M. Miyazaki. 2017. Short communication: Neonatal calves coagulate first-milking colostrum and produce a large curd for efficient absorption of immunoglobulins after first ingestion. J. Dairy Sci. 100:7262-7270. https://doi.org/10 3168/jds.2017-12808.

Moretti, D. B., L. Kindlein, P. Pauletti, and R. Machado-Neto. 2010. IgG absorption by Santa Ines lambs fed Holstein bovine colostrum or Santa Ines ovine colostrum. Animal 4:933-937. https://doi.org/ $10.1017 /$ S1751731110000157.

Moretti, D. B., W. M. Nordi, A. L. Lima, P. Pauletti, I. Susin, and R. Machado-Neto. 2012a. Lyophilized bovine colostrum as a source of immunoglobulins and insulin-like growth factor for newborn goat kids. Livest. Sci. 145:223-229. https://doi.org/10.1016/j.livsci 2012.02.007.

Moretti, D. B., W. M. Nordi, A. L. Lima, P. Pauletti, I. Susin, and R. Machado-Neto. 2012b. Enzyme activity in the small intestine of goat kids during the period of passive immunity acquisition. Small Rumin. Res. 105:321-328. https://doi.org/10.1016/j.smallrumres .2012.01.014.

O'Brien, J. P., and D. M. Sherman. 1993. Serum immunoglobulin concentrations of newborn goat kids and subsequent kid survival through weaning. Small Rumin. Res. 11:71-77. https://doi.org/10 .1016/0921-4488(93)90119-3.
Osaka, I., Y. Matsui, and F. Terada. 2014. Effect of the mass of immunoglobulin $(\mathrm{Ig}) \mathrm{G}$ intake and age at first colostrum feeding on serum IgG concentration in Holstein calves. J. Dairy Sci. 97:66086612. https://doi.org/10.3168/jds.2013-7571.

Quigley, J. D. III, K. R. Martin, and H. H. Dowlen. 1995. Concentrations of trypsin inhibitor and immunoglobulins in colostrum of Jersey cows. J. Dairy Sci. 78:1573-1577. https://doi.org/10.3168/ jds.S0022-0302(95)76780-7.

Rocha, R. X., C. Bondan, R. Marinho, A. T. A. L. Lopes, and M. Cecim. 2007. Dextran iron in anemic lambs: Effects on reticulocytosis and free radical production. Cienc. Rural 37:1344-1348. https:// doi.org/10.1590/S0103-84782007000500019.

Sakai, R. R., D. M. Coons, and M. Chigerwe. 2012. Effect of single oroesophageal feeding of $3 \mathrm{~L}$ versus $4 \mathrm{~L}$ of colostrum on absorption of colostral IgG in Holstein bull calves. Livest. Sci. 148:296-299. https://doi.org/10.1016/j.livsci.2012.06.011.

Tsiligianni, T., E. Dovolou, and G. S. Amiridis. 2012. Efficacy of feeding cow colostrum to newborn lambs. Livest. Sci. 149:305-309. https://doi.org/10.1016/j.livsci.2012.07.016.

Wang, X. X., R. W. Han, X. W. Zhao, D. W. Huang, H. L. Zhu, T. Wu, Y. X. Qi, Y. X. Yang, and G. L. Cheng. 2020. Label-free quantitative proteomics analysis reveals the fate of colostrum proteins in the intestine of neonatal calves. J. Dairy Sci. https://doi .org/10.3168/jds.2020-18439.

Weaver, D. M., J. W. Tyler, D. C. VanMetre, D. E. Hostetler, and G. M. Barrington. 2000. Passive transfer of colostral immunoglobulins in calves. J. Vet. Intern. Med. 14:569-577. https://doi.org/10 .1111/j.1939-1676.2000.tb02278.x.

Wesselink, R., K. J. Stafford, D. J. Mellor, S. Todd, and N. G. Gregory. 1999. Colostrum intake by dairy calves. N. Z. Vet. J. 47:31-34. https://doi.org/10.1080/00480169.1999.36105.

Yang, Y., X. Zhao, D. Huang, J. Wang, Y. Qi, L. Jiang, H. Zhao, and G. Cheng. 2019. Changes in intestinal proteins induced by colostrum uptake in neonatal calves: Analysis by two-dimensional gel electrophoresis-based proteomics analysis. Anim. Prod. Sci. 59:1483-1490. https://doi.org/10.1071/AN18242.

Yvon, M., D. Levieux, M. C. Valluy, J. P. Pélissier, and P. P. Mirand. 1993. Colostrum protein digestion in newborn lambs. J. Nutr. 123:586-596. https://doi.org/10.1093/jn/123.3.586.

Zanker, I. A., H. M. Hammon, and J. W. Blum. 2001. Activities of gamma-glutamyltransferase, alkaline phosphatase and aspartateaminotransferase in colostrum, milk and blood plasma of calves fed first colostrum at $0-2,6-7,12-13$ and $24-25 \mathrm{~h}$ after birth. J. Vet. Med. A Physiol. Pathol. Clin. Med. 48:179-185. https://doi.org/ 10.1046/j.1439-0442.2001.00338.x.

\section{ORCIDS}

H. L. Zhu ๑ https://orcid.org/0000-0001-5273-5090

X. W. Zhao (ㄷ) https://orcid.org/0000-0003-0952-0785

Y. X. Yang ำ https://orcid.org/0000-0002-9596-9636 